\title{
SIX ESSENTIALS TO PERMANENT PEACE
}

\section{By August Schvan,}

Stockholm, Sweden.

A year and a half ago The Lord Chancellor of England passed through New York on his return from the meeting of the American Bar Association in Montreal. Before he embarked he said to a reporter that as far as he could see America would fifty years hence become the leading intellectual nation of the world. At that time, I happened to be in Canada and in a Canadian paper I observed the following comment upon Lord Haldane's utterance. "His only excuse," it said, "for not having seen that the U. S. A. already is the leading intellectual nation is that he only passed two days on American soil." The test whether Lord Haldane or the Canadian editor was right will come at the end of this war. It gives to the United States the greatest opportunity for service to humanity which ever was given to any nation. If the United States seizes that opportunity, I believe, with the Canadian newspaper, that the Lord Chancellor of England made a false statement. The whole of his address to the huge meeting of the prominent lawyers who assembled in Montreal centered in the proposition that "Sittlichkeit" ruled the world to a far greater extent than mere law.

Through the events of the last eight months we have been able to somewhat scrutinize the truth of this proposition. Culture and "Sittlichkeit" have received some startling interpretations.

Let me at once add that this German word might very well be translated into the very good English noun "Righteousness" of which Colonel Roosevelt speaks as often as he wants to impose his own standards upon the rest of the world with the help of the armed forces of this great country. He evidently forgets that righteousness can no longer be an outcome of theological conceptions. He overlooks the timely withering away for inspired doctrines as they have been promulgated in the past either by priests or by emperors.

With the birth of the concept of evolution, righteousness can 
mean nothing else but adaptation to the environment, taken in its largest meaning, that is to say, embracing not only the whole of nature apart from man but also all those human beings who happen to live on this little planet at the same time.

If this definition of righteousness be granted, as it needs must be by all those who care for scientific truth, the real cause of the awful calamity which at present ravages the earth is easily discernible. The disastrous effect of outlived traditions and sepulchred shibboleths becomes apparent.

As far as war and peace are concerned, mankind is moved by ethical, political and economic considerations. Whatever their specific interrelation may be, they no longer correspond to the actual conditions of life. They have one and all a more or less national basis. They must clearly be out of date when the environment of every single individual is no longer a town, a province, a state or a continent but the whole planet, from which every one of us draws more or less in order to satisfy even the simplest material and mental needs.

The ethical conceptions of the so-called civilized world go back to a time when even the most advanced thinkers thought the earth a pancake with a heaven above and a hell below. Its political conceptions are the direct descendants of the doctrines of Imperial Rome confined to the shores of the Mediterranean and surrounded by unknown hordes of savages. Our economic conceptions are still older. They have an almost prehistoric origin when the secret of steam was hidden in every boiling kettle and the greatest labor unions were innumerable isolated tribes.

Yet the nations of the earth have endeavored to regulate their intercourse according to these time-honored and unborn conceptions. No wonder that they have failed! No wonder that the very men who have striven to replace war by peace have so ignominiously drawn the ridicule of the rest of mankind upon themselves. All the empty talk of the pacifists during the last three decades has accomplished nothing but the ludicrous increase of armaments which led to the European war. Their pious inadvertences made the slumbering military interests take to overstating their case, to overemphasize their importance. Belonging to the circles that had close connections with the governments, sprung from those vested interests which control the majority of the advertising 
organs which daily poison the public mind, the spokesmen of armies and navies met the assault of the pacifist with a steadily increasing offensive. The columns of the press were filled with a more intense nationalism than ever before.

At such a time the modern pacifists are proposing to abolish war by the formation of peace leagues, by laying down certain rules for not using the armaments which they are too meek to do away with. What would be thought of anybody who proposed to root out crime by asking the criminals to form societies for not committing murder and burglary and establish certain rules for the use of their implements? How does up-to-date criminal therapeutics proceed? Don't we try to prevent crime by doing away with those causes, with those social conditions as poverty and unwholesome surroundings, which produce criminals?

If we want to see the last of war, we have to proceed in the same manner. The only possible way of abolishing war is to root out nationalism. As long as the pacifists refuse to tackle this side of the question of peace and war, they will continue to "accomplish precisely and absolutely nothing." If we want to make this war the last of all wars, we must preach not internationalism which presupposes nationalism but cosmopolitanism or universalism. We must at once drop all that insidious teaching in nurseries, schools, colleges, universities and on the political platform which arouses the patriotism of the people. We must put those demagogues who want to wield the Big Stick out of commission and let them keep company with those other politicasters who don the shining armor and shake the mailed fist, who long to hold the trident and in the meantime carry on their bloody trade with the help of God. Then and only then will we cease to act as slaves of the past and become the gods of that present, which science has and constantly is unveiling for us in all its limitless and matchless possibilities.

The leading statesmen, or let us rather give them their true name, the shouting politicians, have themselves in so many words told us that statesmanship as it has been evolved out of the history of the dim past has played out its nefarious rôle. In every country they have cried out against the madness of armaments. But at the same time they have taken pains to assure their patient hearers that they could do nothing to stop this insane increase in unpro- 
ductive expenditure which burdens every shoulder to destitution and poverty before it bleeds it in ghastly misery and deadly suffering. They have declared the bankruptcy of modern statesmanship. As a matter of fact, the old historical conception of government has rapidly become obsolete. The state, the nation, have no longer any reason to exist as separate entities, to focus men's attention as they did but a generation ago. Today, for the first time in human history, all national frontiers are practically coterminous. The earth harbors no longer any unknown territories from which surprise attacks can be sprung on civilization. The menace is far greater. It comes from within the very walls of civilization. It springs from the fact that I have already mentioned, that our accepted and blindly obeyed ethical, political and economic conceptions no longer correspond to the real conditions of the planetary epoch.

In this, the most wonderful time that mankind has ever seen, there is no need for national governments as hitherto conceived. The need for their appearance and continuance, the desire for knowledge of the unknown surroundings, the desire for expansion, is no longer an absolute necessity. The conquest of the globe has been accomplished. For the first time in its history, mankind knows the ultimate sphere of its action. The whole of the earth is known and this knowledge has been spread to all its parts. Unless we constantly bear this salient message of our time in our minds, we shall never use our magnificent and unique opportunities to their greatest advantage.

This conquest of the globe by knowledge, by science, or whatever we choose to call it, brings with it the foundations for permanent peace and disarmament, provided we draw all the consequences which it implies. The most important is that the national governments no longer should be allowed to retain any functions of sovereignty outside the borders of their respective nations. The time has come when national governments should occupy the same positions as our municipalities. They should simply become administrative boards over such wide areas as the needs of nationality demand.

Then public international law will become as superfluous as it is fictitious. It can be replaced by a code of international behavior so simple, so definite and so concise, as to be the intellectual in- 
heritance of all men and women in every clime while that fiction which is commonly supposed to regulate the most momentous intercourse between the nations is known only by a few hundred professors of whom no two agree to the exact meaning of the different stipulations of the international law.

In order to establish this code and thereby secure permanent peace, I would suggest that the coming Peace Congress should eliminate the functions of political government from the field of international relations. Though somewhat hidden from the public, this process has already begun. We are today all aware that practically no idea, no discovery, no invention can for any length of time remain purely a national possession. But how many of you realize that there already exist nearly one hundred and fifty international public unions like the postal union, the sugar commission, the institute of agriculture and other similar institutions where national sovereignty is more or less yielding to cosmopolitan experts.

In order to eliminate political influences from international intercourse, in order to do away with that secret diplomacy which has deluged the annals of mankind with oceans of blood, we have but to proceed further on that road. National sovereignty must at all times and in all circumstances stop at the national borders. The state must cease to be an entity opposed to other states. To reach this goal the general acceptance of six cardinal principles should form the basis of the coming peace treaty.

These six are: the principles of nationality; of universal free trade; of a world citizenship; of a planetary jurisdiction; of an oceanic police; and of a standardization of the national police forces.

The principle of nationality I do not need to discuss. It means that every people shall have the right to have that kind of government that it wants to have or is willing to submit to. It is of the essence of peace that all independent communities should be internally so sympathetic that they are willing to grant to others the same rights which they claim for themselves.

The principle of universal free trade is intimately associated with the principle of nationality. The map of Europe cannot be satisfactorily arranged so long as the policy of tariff walls necessitates the violation of the principle of nationality $n$ order to give landlocked races access to the sea. It would be just as unjust to have 
Poles and Bohemians rule over Germans as it is to see the latter have dominance over the former or the Southern Slavs choke under the yoke of Hungary. Universal free trade means the greatest deterrent to war that it is possible to imagine. It means such a specialization, such a diversifying of production, whether industrial or agricultural, that no single area could afford to shut itself off from unhampered intercourse with the rest of the world. Protection has as its moral support the theory that the foreigner should be exploited. Its practical results mean the exploitation of the many by the few who manage to sell their produce at an inflated price behind the Chinese walls which they have raised under the cover of patriotism. It is such an expression of unabashed selfishness that no protectionist should be allowed to talk of justice, rightousness and humanity. On his lips they really are nothing but the worst kind of hypocrisy. With universal free trade, a nation of two million inhabitants will be just as well off as a people of hundred millions because both get the same market, the biggest to be had, the whole earth. Efficiency and industry will reach their proper reward while there will be no reason for conquest in order to enlarge the market. Thus the fallacious cry for a place in the sun will lose much of its driving power.

It will lose all meaning if the principle of a world citizenship is carried out so that every individual, of whatever nationality he may be born, gets the right to be treated everywhere as a full-fledged citizen. The world citizenship means that from the moment anybody is admitted into any country he should in all respects be treated as a citizen of that country. It means that no single individual will put his native country in the absurd position of having to sacrifice thousands and thousands of lives and hundreds of millions of dollars to repair a wrong which if committed within its own borders simply would have resulted in a lawsuit. In relation to those parts of the earth which cannot yet govern themselves, which constitute the white man's burden, the world citizenship should imply the right of admission according to a certain percentage of population. Only thus can the principle of the open door be fully carried out.

If those three principles, of nationality, universal free trade, and world citizenship, are firmly established, diplomacy will become a lost art. Trickery and dishonesty will cease to filter through 
the body politic from above. Foreign offices, embassies, legations and consulates can be shut up provided a jurisdiction is brought to play which can adjust all those legal difficulties arising out of planetary intercourse. But this supreme court of courts must receive the same competence as the supreme court of this country which unlike the present Hague Tribunal is open to appeals from individuals. If national sovereignty stops at the national borders, no government as such should logically be able to come before the supreme court of courts.

The majesty of the law would everywhere gain by such a conception. The state as a personality would be dead. There would in fact be no public law. Everyone would see that the pretended opposition between social and individual aims is a result of the shallow thought of pre-evolutionary days.

The supreme court of courts should be composed of the necessary number of judges allowing a world-wide distribution of its numerous divisions. Those judges should in no sense represent the different nations but the best judicial talents to be found all over the earth. Elected according to the number of the population they should be well paid out of a common fund and with a life appointment so as to be perfectly independent of any national ties.

If national sovereignty is really to stop at the national borders, the high seas should be put entirely under the authority of the supreme court of courts. This would materially enhance its importance and daily bring home to millions of people the entity of humanity. To be able to control the highways of commerce, the supreme court of courts must possess a fleet which would constitute the oceanic police. It need not be very large. Some hundred small eruisers manned by sailors from some small nationalities without political, colonial or economic ambitions like Norway and Denmark would suffice. If need be this force will be quite sufficient to make any national government which should refuse to carry out a judgment delivered by the supreme court of courts come to its senses. With universal free trade, the mere possibility that the ships and floating merchandize belonging to such a nation could be seized by the oceanic police, would secure due respect for the planetary jurisdiction.

Then the pretext for national armies and navies is forever gone. No other armed forces than those necessary for keeping law and 
order within every independent community should be allowed. In order to prevent secret preparations for warlike action it is, however, advisable that the Peace Treaty should standardize the strength of the national police forces. All armament works should be destroyed. We only require an arsenal at Malta, for the oceanic police, a rifle factory in the United States and an ammunition factory in Australia supplying the police forces of al nations according to a fixed schedule.

This may seem to be nothing but a Utopia. So it would be if peace were a matter of prayer and hope. But fortunately permanent peace is a matter of will and intellect. Let the American people who already represent more than one-eighteenth part of mankind take the firm lead on the basis I have outlined and war will soon be a thing of the past. It is so little inherent in human nature that Europe has had to resort to conscription in order to get enough men to fight the cause of the governments, because at the bottom most men are reasonable human beings as soon as they are freed from superstition and ignorance, prejudice and tradition. 